\title{
The Accumulation of People: Slavery and Capitalism in Southern Thought
}

\author{
Jonathan Sudo \\ Haverford College
}

The abolitionist movement in antebellum America provoked a frenzy of pro-slavery reaction. With the very foundation of their society under assault from the 1830s onward, Southern planters, intellectuals and ministers penned countless speeches, essays, letters, and even poems in defense of bondage. Previously, the lack of a movement for immediate abolition gave slaveholders little reason to forcefully argue for the coerced labor of Black people, but the rise of an energized opposition in Britain and America required ever more sophisticated justifications for the "peculiar institution." "The result was that Southern intellectuals began to justify slavery not only in terms of racial hierarchy or practical necessity, but also by critiquing the model of free labor offered by Northern abolitionists as an alternative.

This paper examines pro-slavery arguments against free labor published in prominent Southern periodicals like DuBow's Review. It does not attempt a cohesive examination of the idea of free labor as it developed in antebellum America or try to uncover the lived experiences of either the wage-laborers or slaves discussed. ${ }^{2}$ Rather, it is an examination of southern discourses on free labor with the aim of uncovering what they can tell us about slave owners' conception of themselves as a class and their relationship to a developing industrial capitalism. Specifically, I argue that pro-slavery critiques of free labor did not translate into an antagonism towards capitalism as a whole. Instead, through critiquing free labor, Southerners articulated an alternative vision of capitalism, one based on ostensibly more humane bound labor and the racial and social stability it maintained. However, this vision was fundamentally reactionary and

\footnotetext{
${ }^{1}$ Drew Gilpin Faust, "Introduction," in The Ideology of Slavery: Proslavery Thought in the Antebellum South, 18301860, (Baton Rouge: Louisiana State University Press, 1981), 2-3.

${ }^{2}$ For some accounts of these perspectives, see David R. Roediger, The Wages of Whiteness: Race and the Making of the American Working Class (London: Verso, 2007), Seth Rockman, Scraping By: Wage Labor, Slavery, and Survival in Early Baltimore (Baltimore: The John Hopkins University Press, 2009), Keri Leigh Meritt, Masterless Men: Poor Whites and Slavery in the Antebellum South (Cambridge: Cambridge University Press, 2017), and Ira Berlin, Generations of Captivity: A History of African-American Slaves (Cambridge: Belknap Press, 2004).
} 
situational. It was only articulated in response to attacks from British and Northern abolitionists and, with a few notable exceptions, Southerners never called for its universal implementation.

The scholarly consensus on slavery's relationship to capitalism has evolved significantly over the past several decades. In the late 19th century, the dominant historiographical reading of the Civil War explained it as a conflict between a modernizing, industrial north and a backwards, agricultural south. ${ }^{3}$ Proponents of this theory emphasized the South's lack of a developed industrial infrastructure and planters' critiques of northern wage labor in order to establish fundamental economic and cultural differences between the regions which made their respective systems incompatible. ${ }^{4}$ Recent historians however have challenged this model. Instead of emphasizing how the slave-owning South was backwards compared to the industrial north, they have instead presented the South as deeply enmeshed in the development of a global capitalist economy. In The Half Has Never Been Told for example, Edward Baptist tries to expose this long-neglected half of slavery's history: "how the commodification and suffering and forced labor of Africans Americans is what made the United States powerful and rich." 5 Far from viewing the planter class as ideological enemies of capitalism, Baptist emphasizes the need to understand them as capitalists, devoted to a "modernist, capitalist, entrepreneurial...course of expansion." 6

However, while this new wave of historiography has produced an extensive corpus of literature detailing slavery's relationship with capitalism and modernity, comparatively little attention has been paid to the question of free labor. How are we to reconcile slaveholders' entrenchment in a capitalist economy with their regular critique of something that seems so fundamental to capitalism: the idea of the worker as an autonomous individual freely selling his own labor? The solution thus far has been two-fold. On one hand, scholars have pointed out capitalism's historic dependence on the coerced labor of non-white people to argue that Southerners were hardly unique in their use of Black slaves. Slavery was no less capitalist than free labor. ${ }^{7}$ On the other, scholars have tried to minimize the importance of pro-slavery critiques of free labor by pointing out that the South had its own free labor ideology. Far from attempting

\footnotetext{
${ }^{3}$ Frank Towers, "Parisians, New History, and Modernization: The Historiography of the Civil War's Causes, 1861 2011," The Journal of the Civil War Era 1, no. 2 (2011): 237-264.

${ }^{4}$ One example of this more conservative approach is Elizabeth Fox-Genovese and Eugune D. Genovese, The Mind of the Master Class: History and Faith in the Southern Slaveholders' Worldview, (New York: Cambridge University Press, 2005). The Genoveses examine the public and private writings of slave-owners out of an earnest "admiration for much in their characters and achievements" and come to the conclusion that they were cautious about the rise of market capitalism, viewing it as a dangerous "erosion of binding human relations". (3-5)

${ }^{5}$ Edward E. Baptist, The Half Has Never Been Told: Slavery and the Making of American Capitalism, (New York:

Basic Books, 2016), xxi-ii.

6 Ibid., 390-1.

${ }^{7}$ For instance, see Matthew Karp, This Vast Southern Empire: Slaveholders at the Helm of US Foreign Policy (Cambridge: Harvard University Press, 2016), 1150-172. Karp emphasizes that slaveholders actually recognized the relationship between bound, non-white labor and capitalism at the time. He argues that Southerners constantly stressed the idea that the global capitalist economy was based on the coerced labor of non-whites and in so doing began "to sketch a theory of global modernity that named racial coercion as its single indispensable feature." (153)
} 
to discredit free labor, many Southerners argued that slaves were free laborers in the sense that they were morally and spiritually uplifted by their work. ${ }^{8}$

Neither explanation however fully engages with pro-slavery discourse on free labor so much as tries to ignore it. Emphasizing capitalism's reliance on racialized, coerced labor for instance does little to explain the southern critique of free white labor. Furthermore, emphasizing the South's own free labor ideology ignores how widespread pro-slavery criticisms of northern free labor were, especially in elite circles. Consequently, instead of trying to work around southern critiques of free labor, a more substantive engagement with pro-slavery discourses is necessary to fully unearth slavery's relationship to capitalism.

Probably the biggest reason why recent scholars have paid relatively little attention to southern critiques of free labor is that on the surface they do imply an antagonism towards capitalism that is difficult to incorporate into the dominant model of slaveholders as capitalists. This is especially evident in Southerners' most common argument: that free labor is excessively exploitative and results in the economic destitution of workers. Core to this claim was a rejection of a quintessentially capitalist proposition that profitability is an unqualified good.

For example, in his widely read Memoir on Slavery, South Carolinian planter Judge William Harper compared free and slave labor as part of a larger defense of slavery. First, he described wage labor as it was practiced in England, emphasizing how as population increases, "the remuneration of the laborer becomes gradually less and less; a larger and larger proportion of the product of his labor goes to swell the fortune of the capitalist; inequality becomes still greater and more invidious." The result was that "men will labor for a bare subsistence, and less than a competent subsistence." By contrast, he claimed that under slavery, slaves' "wages" cannot change, such that even "if the income of every planter of the Southern states, were permanently reduced one half, or even much more than that, it would not take one jot from the support and comforts of slaves." Furthermore, unlike wage labor, slaves were provided for their whole lives and not just "during their time of their health and vigor," meaning they were exempt from "the principal source of misery-the wants and sufferings of infancy, sickness, and old age." Harper concluded by claiming that "the accumulation of individual wealth will never be carried to quite so great an extent in a Slave-Holding country, as in one of free labor; but a consequence will be, that there will be less inequality and less suffering." "In other words, Harper used wage labor's greater profitability as a sign of its immorality. The only reason it is more profitable is that it is more brutally extractive.

This argument that while slavery is less profitable than free labor, it is more moral, was constantly reiterated by pro-slavery idealogues during the ante-bellum period. Almost twenty

\footnotetext{
${ }^{8}$ See John Patrick Daly, When Slavery Was Called Freedom: Evangelicalism, Proslavery, and the Causes of the Civil War (Lexington: The University of Kentucky Press, 2002), 111-115 and James L. Huston, Calculating the Value of the Union: Slavery, Property Rights, and the Economic Origins of the Civil War (Chapel Hill: University of North Carolina Press, 2003), 120.

9 Judge Harper, “Memoir On Slavery--Continued From No.1," Southern Literary Messenger 3, no. 2 (February 1838), 83-87.
} 
years later after Harper wrote, the same defense of slavery would be made by an editorial in the Southern Quarterly Review titled "Slavery and Freedom”: "Look into [abolitionists']

declamations.... and it will be manifest that the real argument is simply that free labour is cheaper and more productive or profitable than slave labour. This we do not doubt, if the maximum of profit is wrested from the labourer; but are government, and society, and the human family, created and ordered singly for the production, augmentation, and accumulation of wealth?"10 While this is just one of the more explicit attacks on capitalist ideology made in defense of slavery, every argument premised on the idea that wage workers were materially worse off than slaves implied the same critique.

This attack on an English and northern concern with profitability did constitute a significant critique of capitalism as we commonly understand it, but we should be hesitant in reading too much into this. A disregard for profitability did not preclude a deep economic investment in slavery. For example, several scholars have emphasized the importance of property rather than profitability to slave owners. Specifically, they have pointed out that the total value of slaves in 1860 was $\$ 3$ billion, or 50\% more than the combined value of northern railroads, banks, and manufactures and a desire to protect that investment motivated much of pro-slavery discourse. ${ }^{11}$ Planters were also deeply concerned with the nation's trade and frequently argued that slavery was the source of America's commercial wealth. ${ }^{12}$ This politically manifested itself in a sustained commitment to free trade and opposition to northern attempts to establish protective tariffs. ${ }^{13}$

In other words, a willingness to forgo the profits that came with free labor was fully compatible with a deeply capitalist desire to accumulate wealth and promote free trade. That southern critiques of free labor did not translate into an opposition to capitalism in general is perhaps best demonstrated in southern responses to socialism. Anti-wage labor discourses emerged in response to abolitionist attacks on slavery, yet many abolitionists shared Southerners' critique of northern capitalism. In fact, many prominent abolitionists like Horace Greely were socialists, specifically of the Fourierist tradition. While Fourrier is often dismissed as "utopian socialist," the popularity of his thought in abolitionist circles meant Southerners not only had to defend themselves against an emerging industrial capitalism based on free labor, but an emerging

\footnotetext{
10 "Slavery and Freedom," the Southern Quarterly Review 1, no. 1 (April 1856), 84.

${ }^{11}$ James L. Huston, Calculating the Value of the Union: Slavery, Property Rights, and the Economic Origins of the Civil War (Chapel Hill: The University of North Carolina Press, 2003), 42.

${ }^{12}$ As Matthew Karp explains in Karp, This Vast Southern Empire, 130 Southerners frequently emphasized that southern cash crops like cotton made up a majority of US exports in order to present slavery as the primary source of American's wealth. However, as Karp points out, this stress placed on exports ignored the far larger internal economy: "the value of inland goods arriving in New York City alone in 1860...equaled the value of the whole of southern cotton output that year.

${ }^{13}$ William S. Belko, The Triumph of the Antebellum Free Trade Movement (Gainesville: University Press of Florida, 2019), 148-153.
} 
socialist tradition as well. ${ }^{14}$ A good example of how this impelled pro-slavery intellectuals to more fully develop their thoughts on capitalism is an editorial written in DuBois's Review, one of the most prominent outlets for pro-slavery thought, in 1857: "The War Upon Society Socialism." The editorial began by decrying the rise of "the Black Republicans, or Socialists, of the North, under the lead of Seward, Greely, Garrison, Gerrit Smith, and others" and their assault on the "old and established institutions of the North and South." 15 It then proceeded to make a rigorous defense of those institutions, including both slavery and wage labor.

While the editorial did make the standard critiques of wage labor, claiming "rapid immigration is...crowding the poor out of employment, or reducing their wages to the starving point," it turned the criticism on its head by claiming this was actually positive. Unlike slaves, poor free laborers had the opportunity to go west and establish themselves as free proprietors. Their destitution therefore is not a permanent state, but a powerful stimulus for westward expansion. As a result, "the despotism of Northern capital...becomes a potent agent for the advancement of human good." The editorial even went so far as to claim that free, white agriculture labor would be preferable to slave labor, but that slavery was necessary to prevent the South from becoming "useless to the world and infested by semi-barbarians." However, the editorial's praise of capitalism was contingent upon its relationship to westward expansion and America's manifest destiny. Indeed, it made a clear distinction between free labor as it existed in America and free labor as it existed in Europe, claiming "universal liberty and free competition, are unmitigated evils in old and populous countries, the more active and effective agencies for good in new ones."16

Few Southerners went quite so far as claiming slavery's only benefit was keeping "semibarbarians" in check, but the numerous responses to socialism penned by southern intellectuals similarly argued that wage labor was circumstantially positive. Another editorial in DeBow's Review for example defends the exploitation of workers by "capital owned by others" as the root of civilizational progress, although it does criticize Northern and British capitalists for taking this exploitation too far. ${ }^{17}$ Much more unequivocal is an article published in the pro-slavery Southern Quarterly Review which attacked socialism by arguing for laissez-faire capitalism. ${ }^{18}$

It would consequently be wrong to see in pro-slavery critiques of free labor a blanket denouncement of Northern capitalism, much less capitalism in general. What then can we see in these arguments? The simplest answer is a response to the most common abolitionist attack on slavery: that free labor is superior. This undoubtably was the impetus for much of pro-slavery

\footnotetext{
${ }^{14}$ Adam Tuchinsky, Horace Greely's New-York Tribune: Civil War-Era Socialism and the Crisis of Free Labor (Ithaca: Cornell University Press, 2009) for example emphasizes the need to understand abolitionists like Horace Greely as socialists and not simply dismiss their socialism as utopian (xi-xii).

15 “The War Upon Society - Socialism," DeBow's Review and Industrial Resources, Statistics, etc. Devoted to Commerce, Agriculture, Manufactures 633, (Jun 1857), 688.

${ }^{16}$ Ibid., 689-692.

17 “Article. XII.--Society, Labor, and Capital,” DeBow's Review and Industrial Resources, Statistics, etc. Devoted to Commerce, Agriculture, Manufactures 7, no. 1\&2 (January/February 1862): 134-139.

18 “The Right to Labor," the Southern Quarterly Review 16, no. 31 (October 1849): 138-160.
} 
discourse, but in critiquing free labor, Southerners went beyond just narrowly defending the value of slave labor. A closer reading of pro-slavery discourse reveals that not only was slavery compatible with Northern capitalism, but that through critiquing free labor, Southerners constructed a vision of Southern slavey as a superior form of capitalism.

This model of slave-based capitalism was articulated on two, ultimately contradictory levels: as an ideal economic system universal in its applicability and as a structure of racial and social hierarchy grounded in the particularity of the American South. The first is most visible in Southern attempts to discredit free labor in principle. We have already seen how Southerners frequently argued that wage work was more exploitative than bondage, but they often went even further in asserting the inherent superiority of slavery as a system of labor. Specifically, southern intellectuals claimed that slavery was the basis of capital accumulation and therefore the basis of civilization. Judge Harper for instance in his Memoir on Slavery argued "that slavery anticipates the benefits of civilization, and retards the evils of civilization." He justified this by asserting that "Property-the accumulation of capital, as it is commonly called, is the first element of civilization. But to accumulate, or to use capital to any considerable extent, the combination of labor is necessary." Ordinary, this "combination of labor" is made impossible by men's independence from one another. If all men were free landowners for example, no one "submit to be employed in the service of his neighbor," leaving everyone with only what they and their families can produce on their own. In such a world, people would not "have an income much beyond the necessaries of life," nor time for "intellectual pursuits, or means of acquiring the comforts of elegancies of life." To prevent this grim reality, Harper claimed, some degree of bound labor was necessary, for "if a man has the command of slaves, he may combine labor, and use capital to any required extent, and therefore accumulate wealth."19

Harper thus saw capital accumulation as an inherently exploitative process requiring the submission of one man to another. Rather than take that exploitation as a sign of its immorality however, he instead argued its necessity to civilization. An 1862 editorial in DeBow's Review titled "Society, Labor, Capital, Etc," made a similar argument. It claimed "slavery to skill and capital" was "the price which man pays for civilization" and that only through exploitation and oppression can society progress. By contrast, it argued that "if all lands were in common, and consequently, all men free, all would dress in skins, and live in caves, or hollow trees, or in some equally simple way. ${ }^{20}$

It is important to note that in making this argument, Southerners made a distinction between free labor as an ideal and free labor as it was practiced in the North and Britain. Northern free labor, they claimed, was not really free, but rather another type of slavery. Slaveholders argued that while free laborers were not enslaved in the sense of being owned by their bosses, their dire economic straits left them with little practical freedom: "The master says: 'Work, or I will whip you.' The capitalist, 'Work, or I will starve you." ${ }^{21}$ Despite Northerners'

\footnotetext{
${ }^{19}$ Harper, "Memoir on Slavery," 80.

20 "Society, Labor, Capital, Etc.,"

${ }^{21}$ Ibid., 138.
} 
assertion that they were free, they were just another type of slave. Indeed, according to proslavery discourse which linked slavery, capital accumulation, and civilization, a functioning economy based on free labor was impossible.

In short, Southerners argued that civilization was contingent on capital accumulation and therefore on the slave-labor which was the basis of all capital. The Northern and Southern economies then were both fundamentally the same in that they were both based on the accumulation of capital through the exploitation of slave labor. The primary difference between them was that the South materially provided for its slaves whereas the North did not.

Although Southerners often made a distinction between southern "masters" and Northern "capitalists," this model of slavery was capitalist in its emphasis on capital accumulation. However, from an ideological standpoint, it was clearly a different from the form of capitalism developing in the North and Great Britain. For example, if we examine capitalist ideology as a means of legitimizing a system of economic exploitation, then the vision of slave-based capitalism articulated by Southerners like Dew relied on a distinct set of values. Northern capitalism justified itself by drawing on "bourgeois liberal notions of "possessive individualism"” to argue that the autonomy and "legal self-ownership" of the individual wage-worker made up for his condition. In other words, Northern capitalists claimed that even if laborers owned nothing materially, they were still better off than slaves or serfs in the fact that they owned themselves and their own labor. ${ }^{22}$ The South, however, because it depended on slavery, could not use the same argument to legitimize its form of capitalist exploitation. To compensate for this then, slaveholders invented their own fiction: that slaves, even though they were exploited, were taken care of. In responding to abolitionist attacks on slavery, they shifted the justification for capitalism's obvious inequalities away from a discourse of individual freedom and towards one of workers' material well-being.

This is how Southerners used critiques of free labor to construct a capitalist, pro-slavery ideology, but it is only part of the picture. For example, one of the notable aspects of this attack on the principle of free labor is that it was not racialized. In the previously described arguments, Southerners asserted the necessity of slavery as a universal system of labor, but not as a racialized system of domination. However, American slavery fundamentally was Black slavery, and none of its defenders denied that reality. Articulating the benefits and necessity of Black slavery in particular, and not just slavery in general, thus constituted the second level on which Southerners constructed a model of slave-based capitalism. This mode of argumentation is distinct in that it moved past justifying slavery in the abstract and instead discussed slavery's benefits as a particular system of racial stratification. In doing so, however, Southerners implicitly rejected the universality of their attempts to defend slavery in principle by grounding slavery in the specific racial and social hierarchies of the American South.

22 Jonathan A. Glickstein, Concepts of Free Labor in Antebellum America (New Haven: Yale University Press, 1991), 12. 
It goes without saying that a sense of racial superiority pervaded every defense of bondage. To give just one example, in a widely published speech made to the South Carolinian legislature in 1831, future president of William and Mary College Thomas Roderick Dew, justified slavery on the ground that Black people were naturally indolent and that they would only work when forced to by bondage. Pointing to Haiti as an example, he claimed that free Blacks inevitably descend into idleness which will in turn "produce want and worthlessness, and [their] very worthlessness and degradation will stimulate [them] to deeds of rapine and vengeance." ${ }^{23}$ Simply put, slave-owners like Dew did not believe slaves were fit for freedom and that, if they were emancipated, the result would be violent crime and social chaos. Slavery was consequently essential as a means of disciplining a simultaneously indolent and dangerous race.

However, racism was hardly unique to the South. Northern states extensively regulated their Black populations and Northern visions of free labor were also racialized. ${ }^{24}$ What then did Southerners see as the major benefits of slavery in particular as a system of racial stratification? The key contrast pro-slavery writers maintained was that slavery allowed for the creation of an ideal, white capitalist society free from the disruptions of Northern industrial capitalism.

Again, while Southerners maintained a distinction between southern "masters" or "slaveholders" and Northern "capitalists," they discussed slavery's benefits as a system of racial stratification in distinctly capitalist terms. For example, in defending slavery, southern intellectuals frequently employed a racialized language of capital accumulation to argue that slavery facilitated social mobility for non-slaveholding whites. This is evident in an article in DuBow's Review written by J. D. B. De Bow entitled "The Non-Slaveholders of the South: Their Interest in the Present Sectional Controversy Identical With That of the Slaveholders." Published in 1861, the article's purpose was to convince non-slaveholders that abolitionism was a severe enough threat to their interests that they should support the burgeoning Confederacy. Du Bow explained that one of the greatest benefits of slavery was that it allowed poor whites to easily improve their material condition. If a non-slaveholder saved enough, Du Bow argued, "he can become a slaveholder, and thus relieve his wife from the necessities of the kitchen and the laundry, and his children from the labors of the field." The promise of social mobility through slavery was not just a distant hope, however; it was a tangible reality. According to Du Bow, in 1861 , "twice the number of poor men in the South own a slave, to what owned a slave ten years ago" while "all over the new States of the Southwest enormous estates are in the hands of men who began life as oversees or city clerks, traders and merchants." Furthermore, because they reproduce themselves, slaves were a form of capital with natural gains: "If a woman, her children become heirlooms, and make the nucleus of an estate," then "a plantation of fifty or sixty persons has been established from the descendants of a single female, in the course of the lifetime of the

\footnotetext{
${ }^{23}$ Thomas Roderick Dew, "Abolition of Negro Slavery," in The Ideology of Slavery: Proslavery Thought in the Antebellum South, 1830-1860, ed. Drew Gilpin Faust, (Baton Rouge: Louisiana State University Press, 1981), 56-7. ${ }^{24}$ See Roediger, The Wages of Whiteness.
} 
original purchaser." ${ }^{25}$ Du Bow did not explicitly state it, but by defending slavery's unique ability to facilitate upward mobility in the face of abolitionist pressure, he made an implicit contrast with the North. Both the North and South might promise a better future for poor whites, but only the Southern slavery realistically delivered on that promise. While this article is just one example, slaveholders frequently echoed Du Bow's claim that slavery was the basis for white social mobility in order to gain the support of non-slaveholding whites during the Civil War. ${ }^{26}$

However, on top of arguing that Black slavery better delivered on capitalism's promise of social mobility, Southern intellectuals also asserted that slavery prevented the worst evils of capitalism that were then visible in the North. For example, pro-slavery writers argued that unlike in the North where capitalism was producing heightened class tensions, slavery preserved a sense of racial and social solidarity among the white population. In his defense of slavery for instance, Thomas Roderick Dew claimed that because "the menial and low offices" were all occupied by Black people, "the greatest cause of distinction and separation of the ranks of society" among whites was removed. As a result, Dew argued, in the South "you [could] find that no white man feels such inferiority of rank as to be unworthy of association with those around him." He concluded by asserting: "it is this spirit of equality which is both the generator and preserver of the genuine spirit of liberty." 27.

J. D. B. Du Bow made a similar argument in emphasizing social inequality produced by Northern free labor. Du Bow claimed that unlike "the poor white laborer at the North" who sat "at the bottom of the social ladder" and was looked down upon, "no white man at the South serve[d] as a body-servant." Instead, even when in the employ of another white, Southerners were always "a companion and an equal": "if a distinction exists, it is only that which education and refinement may give, and this is so courteously exhibited as scarcely to strike attention." ${ }^{28}$ In other words, Southerners argued that unlike in the North, where free labor-based capitalism was producing ever-greater social inequality and tension, slavery preserved egalitarianism and mutual respect among the white community by creating a permanent underclass of Black slaves.

However, slavery did not produce a more stable society just by creating a sense of racial solidarity and equality among whites. It also did so by preserving a homogenous white population. Returning to De Bow's editorial again, another positive aspect of slavery he stressed was that it did not facilitate immigration. Whereas in the North, the need for a surplus of laborers attracted an influx of immigrants looking for work, immigrants' inability to economically compete with slaves discouraged them from entering the South. As a result, the South was able to "maintain a more homogenous population, and show a less admixture of races, than the North." This was positive in the long run because it maintained social stability. In the North, Du

\footnotetext{
${ }^{25}$ J. D. B. De Bow, "Art. VI.-The Non-Slaveholders of the South: Their Interest in the Present Sectional Controversy Identical With That of the Slaveholders," DeBow's Review and Industrial Resources, Statistics, etc. Devoted to Commerce, Agriculture, Manufactures 5, no. 1 (January 1861): 74.

${ }^{26}$ Baptist, The Half Has Never Been Told., 390-1.

${ }^{27}$ Dew, "Abolition of Negro Slavery," 67.

${ }^{28}$ De Bow, "Art. VI-The Non-Slaveholders of the South," 73.
} 
Bow argued, "the competition between native and foreign labor" had "already begotten rivalry, and heart-burning, and riots, which have been marked by a degree of hostility and proscription to which the present age has not afforded another parallel." The South, however, by preventing an influx of foreign populations, continued to "partake of the true American character" and existed in a state of social harmony. Instead of entertaining disruptive foreign importations and becoming Owenites, Socialists, or Freelovers, Southerners adhered "to the simple truths of the Gospel" and held faith in "law, order, and existing institutions. ${ }^{29 "}$

The idea that slavery prevented an influx of immigrants and the social ills that accompanied them again appeared in "The Prospects and Policy Of the South, As They Appear to the Eyes of a Planter," an article published in the Southern Quarterly Review in 1854 and written by South Carolinian planter Frederick Porcher. In the article, Porcher contrasted the prospects of the North and South. One of the main points of comparison he made was the relative increase in population. Whereas in the South, the abolishment of the slave trade prevented an influx of new laborers, the North's laboring population was constantly growing with new arrivals from Europe. The result was a growing demographic and economic inequality between the regions. On the surface, this inequality disadvantaged the South, but Porcher argued that in the long run, the wealth immigration created came at the cost of America's "patrimony." Specifically, Porcher claimed the influx of poor Europeans had eroded republican tradition in the North. What had once been a "republic, born and fostered under Anglo-Saxon institutions," had all but disappeared as foreigners and foreign ideas entered the country: "the old conservative elements of Anglo-Saxon freedom have given way to the wild notions of democracy entertained by every people of Europe who have never enjoyed and are unable to conceive the blessings of true liberty." ${ }^{30}$ Porcher concluded by calling for the legalization of the slave trade, arguing that it would be better to allow in slaves "who never could affect [America's] political state" rather than open the country to "others who threaten to destroy [it]", i.e. immigrants.

If on an abstract level then, Southerners articulated a model of slavery as a more humane, transparent form of capitalism, they also argued slavery and the racial hierarchy it maintained prevented capitalism's most socially disruptive effects. Unlike in the free North, the slaveholding South had no class anxieties, no disruptive immigrants, and thus no conflicts among the white population. However, these two lines of argument subtly contradicted one another. Asserting that slavery was in principle superior to "free labor," either as an ideal or a specific practice, implied a universality that was directly challenged by Southerners' model of slavery as an actual system grounded in racial hierarchy and social homogeneity. In other words, while slaveholders were arguing that all workers, even white workers, are slaves or would be better taken care of if enslaved, they could only understand slavery to mean Black slavery.

\footnotetext{
${ }^{29}$ Du Bow, “Art. VI-The Non-Slaveholders of the South,” 73.

${ }^{30}$ Frederick Porcher, "The Prospects and Policy of the South, as they Appear to the Eyes of a Planter-Considerations Occasioned by the Proceedings of the Late Commercial Convention, Held in Charleston, S. C.," the Southern Quarterly Review, no 20. (October 1854), 435-6.
} 
This contradiction was recognized by George Fitzhugh, one of the more controversial southern ideologues. In "Southern Thought," an article published in DuBow's Review in 1857 for example, Fitzhugh chided his fellow Southerners for being too timid in their defense of slavery. Rather than justify simply "negro slavery," Fitzhugh argued the South needed to justify "the slavery principle, justify slavery as natural, normal, and necessitous." Specifically, he argued that intellectuals need to press for the enslavement of whites, claiming "emancipation of the white serfs or villains was a far more cruel failure, so far as those serfs were concerned, than West Indian emancipation." 31

What is perhaps most notable about Fitzhugh's work is that despite being one of the most widely read pro-slavery writers of the 1850 s, almost no one was willing to endorse his radical prescriptions. This was despite almost every Southern intellectual agreeing with the premise of his argument. As we have seen, Fitzhugh was not entirely correct in claiming that Southerners refused to justify slavery in principle. They did. The key difference between them was that most simply failed to follow Fitzhugh in taking the logical next step: they never called for the abolition of free labor.

This contradiction between slaveholders' argument that slavery was superior in principle to free labor and their unwillingness to advocate for slavery as anything other than a specific, racialized system of power highlights the fundamentally reactionary nature of southern thought. By reactionary, I do not mean that it was backward or anti-modern, but rather that Southerners articulated their unique model of a slave-based capitalism not as a proactive, positive vision of how the world should be, but as a defensive maneuver in a battle against abolitionism. Southerners almost always framed pro-slavery critiques of free labor as a response to particular abolitionist criticisms. As a result, no matter how bold their claims could be, pro-slavery writers were primarily defending the status quo. It is thus not surprising that slaveholders almost never went so far as to call for the enslavement of whites or a return to serfdom even though it was the logical conclusion of many of their arguments. To do so would have required calling for a radical transformation of the society that was far outside the purview of what they were trying to accomplish: namely the preservation of slavery where it existed.

Emphasizing the reactionary nature of pro-slavery discourse is important as it requires scholars to qualify their attempts at historical revisionism. Certainly, the South was neither materially nor ideologically opposed to capitalism as historians in the late 20th century claimed. Even in southern critiques of as quintessentially capitalist a concept as free labor, we can see a project of articulating a model of slave-based capitalism distinct from the type of capitalism developing contemporaneously in the North. However, all the intellectual energy, so to speak, originated on the northern side of the Mason-Dixon line. The South was only responding to the discourses of the North, specifically to an abolitionist discourse based on a mix of socialism, laissez-faire capitalism, and free labor ideology. Consequently, it is questionable whether we can

\footnotetext{
${ }^{31}$ George Fitzhugh, “Southern Thought," DeBow's Review and Industrial Resources, Statistics, etc. Devoted to Commerce, Agriculture, Manufactures 337 (October 1857), 337-339.
} 
say there was no difference in the capitalist orientation or "progressiveness" of the North and South as recent historiography suggests. To do so not only ignores the defensive posture assumed by the South, but also the reality that while free labor ideology still exists, no one would turn to slavery as the ideal basis for an economy. 


\section{Bibliography}

\section{Primary Sources:}

“Article. XII.--Society, Labor, and Capital.” DeBow’s Review and Industrial Resources, Statistics, etc. Devoted to Commerce, Agriculture, Manufactures 7, no. 1\&amp;2 (January/February 1862): 134-139.

De Bow, J. D. B. “Art. VI.-The Non-Slaveholders of the South: Their Interest in the Present Sectional Controversy Identical With That of the Slaveholders." DeBow's Review and Industrial Resources, Statistics, etc. Devoted to Commerce, Agriculture, Manufactures 5, no. 1 (January 1861): 67-77.

Fitzhugh, George. "Southern Thought." DeBow's Review and Industrial Resources, Statistics, etc. Devoted to Commerce, Agriculture, Manufactures 337 (October 1857): 336-354.

Harper, Judge. "Memoir On Slavery: Read before 'the South Carolina Society for the Advancement of Learning." Southern Literary Messenger 4, no. 10 (October 1838): 612622.

Porcher, Frederick. "The Prospects and Policy of the South, as they Appear to the Eyes of a Planter--Considerations Occasioned by the Proceedings of the Late Commercial Convention, Held in Charleston, S. C." the Southern Quarterly Review, no 20 (October 1854), 431-457.

“Slavery and Freedom.” the Southern Quarterly Review 1, no. 1 (April 1856): 62-95.

Faust, Drew Gilpin, ed. The Ideology of Slavery: Proslavery Thought in the Antebellum South, 1830-1860. Baton Rouge: Louisiana State University Press, 1981.

“The Right to Labor.” the Southern Quarterly Review 16, no. 31 (October 1849): 138-160.

“The War Upon Society - Socialism.” DeBow's Review and Industrial Resources, Statistics, etc. Devoted to Commerce, Agriculture, Manufactures 633 (Jun 1857), 633-644.

\section{Secondary Sources:}

Baptist, Edward E. The Half Has Never Been Told: Slavery and the Making of American Capitalism. New York: Basic Books, 2016.

Belko, William S. The Triumph of the Antebellum Free Trade Movement. Gainesville: University Press of Florida, 2019.

Berlin, Ira. Generations of Captivity: A History of African-American Slaves. Cambridge: Belknap Press, 2004. 
Daly, John Patrick. When Slavery Was Called Freedom: Evangelicalism, Proslavery, and the Causes of the Civil War. Lexington: The University of Kentucky Press, 2002.

Faust, Drew Gilpin. "Introduction.” In The Ideology of Slavery: Proslavery Thought in the Antebellum South, 1830-1860. Baton Rouge: Louisiana State University Press, 1981.

Fox-Genovese, Elizabeth and Eugene D. Genovese. The Mind of the Master Class: History and Faith in the Southern Slaveholders' Worldview. New York: Cambridge University Press, 2005.

Glickstein, Jonathan A. Concepts of Free Labor in Antebellum America. New Haven: Yale University Press, 1991.

Huston, James L. Calculating the Value of the Union: Slavery, Property Rights, and the Economic Origins of the Civil War. Chapel Hill: University of North Carolina Press, 2003.

Meritt, Keri Leigh, Masterless Men: Poor Whites and Slavery in the Antebellum South. Cambridge: Cambridge University Press, 2017.

Karp, Matthew. This Vast Southern Empire: Slaveholders at the Helm of US Foreign Policy. Cambridge: Harvard University Press, 2016.

Rockman, Seth. Scraping By: Wage Labor, Slavery, and Survival in Early Baltimore. Baltimore: The John Hopkins University Press, 2009.

Roediger, David R. The Wages of Whiteness: Race and the Making of the American Working Class. London: Verso, 2007.

Towers, Frank. "Parisians, New History, and Modernization: The Historiography of the Civil War's Causes, 1861-2011." The Journal of the Civil War Era 1, no. 2 (2011): 237-264.

Tuchinsky, Adam. Horace Greely's New-York Tribune: Civil War-Era Socialism and the Crisis of Free Labor. Ithaca: Cornell University Press, 2009. 